Eur J Clin Chem Clin Biochem

1995; 33:699-704

(c) 1995 Walter de Gruyter \& Co.

Berlin - New York

\title{
Ochratoxin A Impairs Activity of the Membrane Bound Enzymes in Rat Pancreas ${ }^{1}$ )
}

\author{
By Tihana Žanić-Grubišić, Renata Zrinski, Ivana Čepelak, Joszef Petrik and Stjepan Pepeljnjak \\ Department of Medical Biochemistry, Faculty of Pharmacy and Biochemistry, University of Zagreb, Zagreb, Croatia
}

(Received January 2/May 8, 1995)

Summary: Ochratoxin A is a mycotoxin produced by Aspergillus ochraceus and is a natural contaminant of moldy food. Ochratoxin A has a number of toxic effects, some of which may be related to the changes in the cell membrane. We measured the activities of 5 pancreatic, membrane bound enzymes in female Fisher rats that were

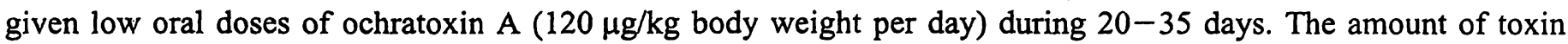
corresponds to $1.5 \mathrm{mg} / \mathrm{kg}$ in the feed, daily. These doses are in the range of natural contamination found in feed. The enzymes studied were alanine aminopeptidase, alkaline phosphatase, ecto- $\mathrm{Ca}^{2+} / \mathrm{Mg}^{2+}$-ATPase, $\gamma$-glutamyl transferase and ecto-5'-nucleotidase. Treatment lasting 20 days caused a strong decrease in the activity of alanine aminopeptidase, $\mathrm{Ca}^{2+} \mathrm{Mgg}^{2+}$-ATPase and alkaline phosphatase to $0.76 \pm 0.04,0.53 \pm 0.03$ and $0.30 \pm 0.02$ of the control values, respectively $(\mathrm{p}<0.05)$. No significant changes in the activity of $\gamma$-glutamyl transferase and 5 'nucleotidase were observed. However, activity of alanine aminopeptidase returned to normal values after 35 days of treatment, suggesting an adaptation of the organism, or a substitution of a released enzyme. Activities of alkaline phosphatase and $\mathrm{Ca}^{2+} / \mathrm{Mg}^{2+}$-ATPase remained significantly reduced to $0.42 \pm 0.03$ and $0.52 \pm 0.04$, respectively $(p<0.01)$. We conclude that treatment of rats with low doses of ochratoxin A resulted in reduction of the activities of the membrane bound enzymes, most probably by inducing their release, as a result of the impairment of the functional integrity of cell membranes.

\section{Introduction}

Ochratoxin A is a nephrotoxic, hepatotoxic and teratogenic mycotoxin produced by storage molds (chiefly by species of Aspergillus and Penicillium) on a variety of commodities. Exposure to low concentrations of this toxin causes morphological and functional changes in kidney of several domestic and experimental animals. The toxin has also been found in human sera from people living in areas where Balkan endemic nephropathy occurs, and it is suggested to be a possible determinant of this fatal human disease (1).

Numerous studies have identified the proximal tubule as the most important intrarenal target and it is well documented that ochratoxin A causes glucosuria, a decrease

\footnotetext{
$\left.{ }^{1}\right)$ This work has been supported by The Ministry of Science and Technology of Croatia, project \# 1-07-102.
}

in the transport of organic anions and mitochondrial dysfunction in kidney (2-4). Inhibition of mitochondrial respiration and oxidative phosphorylation, as well as decreased rate of protein synthesis and decreased rate of RNA synthesis, were described in liver (5). The weak non-mutagenic genotoxicity and carcinogenicity were shown for mice and rats and major target organs were kidney and liver (6-8). The mechanism responsible for the diverse toxic effects produced by ochratoxin $\mathrm{A}$ has not yet been identified. Competition with phenylalanine hydroxylase and other enzymes that accept phenylalanine as a substrate is based on the structural homology of ochratoxin A with this amino acid (9). Recently it was found that ochratoxin A greatly enhances the rate of NADPH dependent lipid peroxidation (10). Enhanced peroxidation of polyunsaturated fatty acids from membrane lipids might seriously impair cell membrane integrity, and 
produce structural and functional changes eventually leading to cellular necrosis (11).

Ochratoxin A affects carbohydrate metabolism in rats, producing an increase in blood glucose and a concomitant decrease in glycogen in liver. The increase in the blood glucose level was accompanied by decreased levels of insulin during ochratoxin A treatment of rats (2). Induction of hyperglycaemia associated with hypoinsulinaemia were also produced with other mycotoxins like terreic acid and pemitrem A (12). It has been shown that ${ }^{14} \mathrm{C}$-labelled ochratoxin $\mathrm{A}$ accumulates in pancreas after low dose intravenous injection $(13,14)$. Berndt et al. found that repeated low doses given to rats produced accumulation of the toxin in susceptible tissues, which resulted in excessive weight loss and diarrhea, perhaps related to the impairment of exocrine pancreatic function (15). However, although the toxicity of ochratoxin $\mathrm{A}$ is extensively studied, only limited attention has been directed toward changes produced in the pancreatic tissue. Therefore we decided to study effects of ochratoxin $A$ on the pancreas and especially on pancreatic plasma membranes.

The main goal of this study was to determine changes in the activities of enzymes bound to the pancreatic cell membrane, as a result of administration of repeated low doses of ochratoxin A (120 $\mu \mathrm{g} / \mathrm{kg}$ body weight) during 20 and 35 days of treatment. This dose corresponds to an average in the feed of $1.5 \mathrm{mg} / \mathrm{kg}$ each day, a concentration that may be encountered in naturally contaminated food products (16). However, in our previous work we observed changes in the activities of kidney brush border enzymes induced by a similar regimen of ochratoxin A treatment. Increased activities of rat renal brush border enzymes in urine were found when low doses of ochratoxin A were applied for 20 and 30 days (17). The enzymes in this study were chosen as indicators for the stability of pancreatic cell membranes. The selected enzymes ${ }^{2}$ ) ecto-5'-nucleotidase, ecto- $\mathrm{Ca}^{2+} / \mathrm{Mg}^{2+}$ ATPase, alanine aminopeptidase, alkaline phosphatase and $\gamma$-glutamyl transferase exhibit different localization and linkage on the phospholipid bilayer of the cell membrane. A different degree of release of a particular enzyme might be indicative for the mode of the toxic action of ochratoxin $\mathrm{A}$ on the pancreatic cell membrane.

\footnotetext{
2) Enzymes:

Alanine aminopeptidase, ( $\alpha$-aminoacyl-peptide hydrolase, EC 3.4.11.2);

Alkaline phosphatase, (orthophosphoric monoester phosphohydrolase (alkaline optimum), EC 3.1.3.1);

$\gamma$-Glutamyl transferase, $(\gamma$-glutamyl-peptide : aminoacid $\gamma$-glutamyl transferase EC 2.3.2.2);

ecto-5'-nucleotidase, (5'-ribonucleotide phosphohydrolase, EC 3.6.1.5)

ecto- $\mathrm{Ca}^{2+} / \mathrm{Mg}^{2+}$-ATPase, (ATP-phosphohydrolase, EC 3.6.1.5)
}

\section{Materials and Methods}

\section{Materials}

Ochratoxin A was obtained by biosynthesis from culture of Aspergillus sulphureus NRRL 4077 on wheat kernels with $40 \%$ bumidity. Isolation procedure was essentially according to 1 . c. (18). The white crystalline material was tested for purity by thin-layer chromatography and then identified as abright blue fluorescent spot under short wave UV light (19). The concentration of ochratoxin A was determined spectrophotometrically at $333 \mathrm{~nm}$ in methanol, assuming a molar absorbance of $550 \mathrm{~m}^{2} / \mathrm{mol}$ (1).

\section{Animals}

Adult albino female rats of Fisher strain weighing between 150 and $200 \mathrm{~g}$ were used for the experiments. The animals were given food and water ad libitum, (food - standard laboratory pellets, declared not to contain mycotoxins, PLIVA d.d., Zagreb, Croatia). Rats were divided into experimental $(n=10)$ and control $(n=5)$ groups.

\section{Group A - 20 days treatment}

Daily dose of ochratoxin A $120 \mu \mathrm{g} / \mathrm{kg}$ body weight (dissolved in a volume of $0.5 \mathrm{ml}$ of $0.051 \mathrm{mmol} / 1 \mathrm{NaHCO}_{3}$ ) was administered to experimental animals each morning by gastric intubation. Animals were sacrificed after 20 days of treatment. Total amount of ochratoxin A given was $400 \mu \mathrm{g}$ ochratoxin A per animal.

\section{Group B - 35 days treatment}

The animals received the same daily dose during 35 days, corresponding to total amount of $720 \mu \mathrm{g}$ ochratoxin A per animal.

\section{Controls}

The control animals received daily dose of $0.5 \mathrm{ml}$ of $0.051 \mathrm{mmol} / \mathrm{l}$ $\mathrm{NaHCO}_{3}$ for 20 and 35 days, respectively.

\section{Isolation of pancreatic plasma membranes}

Rats were sacrificed by cervical dislocation after light ether anesthesia. Pancreas was homogenized at $4{ }^{\circ} \mathrm{C}$ in an Ultra-turrax homogenizer in $5 \mathrm{mmol} / \mathrm{l}$ Tris-Hepes buffer ( $\mathrm{pH} \mathrm{7.0)}$ ), containing 280 $\mathrm{mmol} / 1 \mathrm{mannitol}, 10 \mathrm{mmol} / 1 \mathrm{KCl}, 1 \mathrm{mmol} / \mathrm{MgCl}, 1 \mathrm{mmol} / 1$ benzamidine and $0.1 \mathrm{~g} / \mathrm{l}$ soybean trypsin inhibitor. The homogenates were centrifuged for $15 \mathrm{~min}$ at $1000 \mathrm{~g}$ and supernatant was further centrifuged at $13000 \mathrm{~g}$ for $20 \mathrm{~min}$. Pellets containing cell membranes were resuspended in $1 \mathrm{ml}$ of the same buffer, vesiculated and centrifuged for $30 \mathrm{~min}$ at $18000 \mathrm{~g}$. The final pellet, containing plasma membranes was resuspended and vesiculated in $0.5 \mathrm{ml}$ of the $500 \mathrm{mmol} / \mathrm{h}$ Tris-Hepes buffer $(\mathrm{pH}$ 7.4) and saved for enzyme analysis. The analyses of the enzyme activity were performed with the fresh membrane preparations.

\section{Enzyme assays}

Determination of the activity of ecto- $\mathrm{Ca}^{2+} / \mathrm{Mg}^{2+}-\mathrm{ATP}$ ase and ecto5 '-nucleotidase was performed in $0.5 \mathrm{ml}$ of reaction medium containing (final concentrations) $50 \mathrm{mmol} / \mathrm{l}$ Tris-Hepes $\mathrm{pH} \mathrm{7.4,10}$ $\mathrm{mmol} / \mathrm{l} \mathrm{KCl}$ and inhibitors of other ATPases, $0.1 \mathrm{mmol} / \mathrm{h}$ levamisole, $0.1 \mathrm{mmol} / 1$ ouabain, $0.1 \mathrm{mmol} / \mathrm{l} \mathrm{N}$-ethyl-maleimide, 0.1 $\mathrm{mmol} / \mathrm{l}$ sodium azide, $1 \mathrm{mmol} / \mathrm{MgCl}$ and $0.030 \mathrm{mg}$ of proteins in the presence of $1 \mathrm{mmol} / \mathrm{l}$ substrate. Substrate for the determination of ecto- $\mathrm{Ca}^{2+} / \mathrm{Mg}^{2+}$-ATPase activity was $1 \mathrm{mmol} / \mathrm{l}$ ATP and for ecto-5'-nucleotidase activity $1 \mathrm{mmol} / \mathrm{h}$ AMP (20). The liberated inorganic phosphate was measured by the method of Fiske and SubbaRow (21). Alanine aminopeptidase was determined according 
to Jung \& Scholz (22) with $0.7 \mathrm{mmol} / \mathrm{l}$ of alanine- $\beta$-naphthylamide as substrate, $\gamma$-glutamyl transpeptidase according to $S z a \bar{z} z$ (23) with $\gamma$-glutamyl-4-nitroanilide as substrate and alkaline phosphatase according to IFCC recommendations.

Protein concentration was determined according to Bradford (24) using bovine serum albumin as a standard. Spectrophotometric measurements were performed on the Unicam SP $8 \times 100$ Spectrophotometer.

\section{Chemicals}

All biochemicals, including coenzymes, substrates and auxiliary enzymes were of analytical grade purchased from Sigma Chem. Co. (St Louis, Mo, USA), or Boehringer (Mannheim, Germany).

\section{Statistics}

The data are presented as mean values \pm SEM.

Significance of the difference was tested by Mann-Whitney U-test. Values were considered significantly different if $p<0.05$.

\section{Results}

In this paper we studied the changes that occur in the pancreatic plasma membrane following 3-5 weeks of daily, oral application of low doses of ochratoxin $A$ to rats. Activities of membrane bound ecto- $\mathrm{Ca}^{2+} / \mathrm{Mg}^{2+}$ ATPase, ecto-5'-nucleotidase, alanine aminopeptidase, $\gamma$-glutamyl transferase and alkaline phosphatase were selected as indicators of the functional integrity of the cell membrane.

In the preliminary experiments we found detectable concentration of ochratoxin $\mathrm{A}$ in the pancreas following acute and prolonged treatment with low doses of the toxin. When inspected under UV light, pancreatic tissue showed fluorescence characteristic for the presence of ochratoxin A (results not shown). The serum level of ochratoxin A was measured according to Hult et al., and was found to be $300 \mu \mathrm{g} / 1$ following 35 days of treatment (1). Table 1 shows the effects of ochratoxin A on body weight, pancreas weight and protein content in pancre- atic tissue. The experimental animals that were receiving daily doses of $120 \mu \mathrm{g} / \mathrm{kg}$ body weight of ochratoxin A during 35 days showed a significant decrease in the body weight gain of about $75 \%$ and decreased protein concentration in the homogenates prepared from the pancreatic tissue, in comparison to the control group. We suppose that the combination of the reduction in the food intake and inhibition of the protein synthesis might both be contributing to the effects measured.

Data concerning activities of the enzymes in the pancreatic plasma membrane are very scarce, therefore we first had to establish control values for the enzyme activities that would be used as the reference for the comparison. Table 2 represents the activities of: ecto- $\mathrm{Ca}^{2+} / \mathrm{Mg}^{2+}$ ATPase, ecto-5'-nucleotidase, alanine aminopeptidase, $\gamma$-glutamyl transferase and alkaline phosphatase in pancreatic plasma membrane of control animals. The activity of the enzymes tested did not significantly change between the two experimental time points.

Changes in the activities of the pancreatic membrane bound enzymes following 20 and 35 days of treatment, respectively, are shown in the figure 1 . From the results presented, it is evident that ochratoxin A produced a

Tab. 2 Enzyme activities in pancreatic plasma membranes of control rats

\begin{tabular}{|c|c|c|}
\hline \multirow[t]{2}{*}{ Enzyme } & \multicolumn{2}{|c|}{$\begin{array}{l}\text { Enzyme activity } \pm \mathrm{SEM}^{\mathrm{a}} \\
\left(\mu \mathrm{mol} \mathrm{min}^{-1} \mathrm{mg}^{-1} \text { protein }\right)\end{array}$} \\
\hline & 20 days & 35 days \\
\hline$\gamma$-Glutamyl-transferase & $0.419 \pm 0.026$ & $0.460 \pm 0.013$ \\
\hline Alanine aminopeptidase & $0.762 \pm 0.021$ & $0.721 \pm 0.018$ \\
\hline Alkaline phosphatase & $18.6 \pm 2.6$ & $15.8 \pm 1.92$ \\
\hline ecto- $\mathrm{Ca}^{2+} / \mathrm{Mg}^{2+}-$ ATPase & $17.5 \pm 1.51$ & \pm 1.92 \\
\hline ecto-5'-nucleotidase & $8.41 \pm 0.4$ & $7.21 \pm 0.32$ \\
\hline
\end{tabular}

a Data are presented as mean \pm SEM for the control animals that were receiving $0.5 \mathrm{ml}$ of $0.051 \mathrm{mmol} / 1 \mathrm{NaHCO}_{3}$ for 20 days $(n=5)$ and $35(n=5)$, respectively.

Tab. 1 Effects of ochratoxin A treatment on the gain in body weight, pancreas weight and protein content in the pancreatic tissue

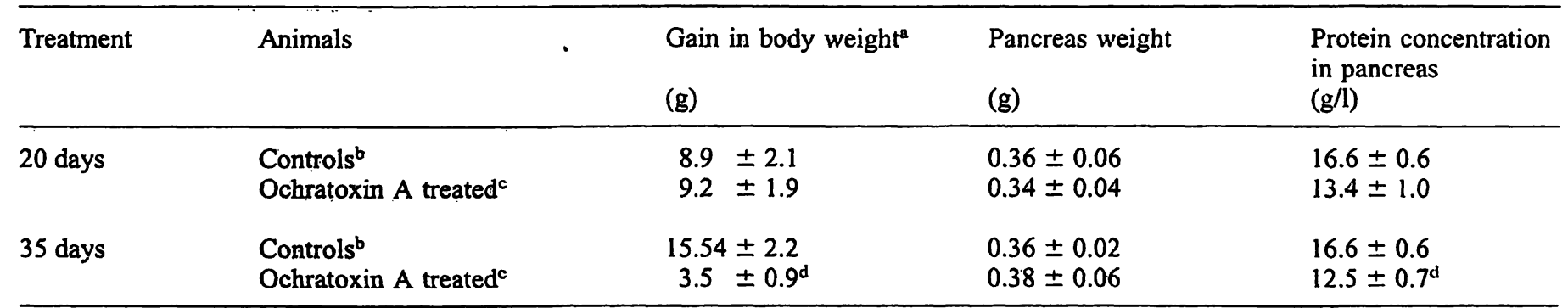

Data are presented as mean $\pm \operatorname{SEM}$ from control $(n=5)$ and treated $(n=10)$ animals.

a The gain in the body weight was measured for 20 and 35 days, respectively.

b Controls received $0.5 \mathrm{ml}$ of $0.051 \mathrm{mmol} / \mathrm{A} \mathrm{NaHCO}$, daily. c Ochratoxin A treated animals received ochratoxin $A$ at a daily' dose of $120 \mu \mathrm{g} / \mathrm{kg}$ body weight dissolved in $0.5 \mathrm{ml}$ of $0.051 \mathrm{mmol} / 1$ $\mathrm{NaHCO}_{3}$, for the indicated number of days.

d Statistical significance of the difference between treated and control rats at the confidence level $\mathrm{p}<0.05$. 


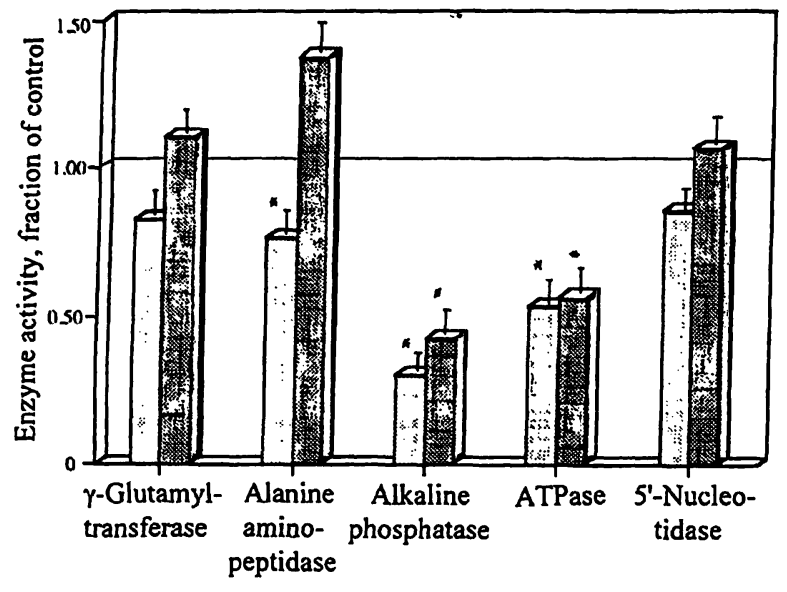

Fig. 1 Enzyme activities in isolated pancreatic plasma membranes of rats treated with ochratoxin A for $20(\square)$ and $35($ (日) days. Data are presented as fraction of control values (mean \pm SEM) from 10 separate membrane preparations.

(*) Statistical significance of the difference between treated and control rats at the confidence level $\mathrm{p}<0.05$.

decrease in alanine aminopeptidase, alkaline phosphatase and ecto- $\mathrm{Ca}^{2+} / \mathrm{Mg}^{2+}$-ATPase, already after 20 days of treatment. Activities of alanine aminopeptidase, ecto$\mathrm{Ca}^{2+} / \mathrm{Mg}^{2+}$-ATPase and alkaline phosphatase were reduced in comparison to the controls, and the fraction of the remaining activities were $0.76 \pm 0.04,0.53 \pm 0.03$ and $0.30 \pm 0.02$, respectively. Changes in the activities of $\gamma$-glutamyl transferase and 5'-nucleotidase were not statistically significant. In the prolonged course of treatment, following 35 days of ochratoxin A intoxication, only the activity of alanine aminopeptidase returned to control values. However, it is worth mentioning that 5'nucleotidase, alanine aminopeptidase and $\gamma$-glutamyl transferase could be found in cytosolic and in membrane bound fractions in the cell $(25-27)$. The observed normalization may be a result of the novel redistribution of the enzyme isoforms between those two compartments. In contrast to these results catalytic concentration of ecto- $\mathrm{Ca}^{2+} / \mathrm{Mg}^{2+}$-ATPase and alkaline phosphatase remained significantly reduced at $0.56 \pm 0.04$ and 0.42 \pm 0.03 of the control values, on day 35 of the experiment. It seems that normalization of catalytic concentrations of $\mathrm{Ca}^{2+} / \mathrm{Mg}^{2+}$-ATPase and alkaline phosphatase might require the synthesis of new protein molecules, a process that is seriously impaired by ochratoxin A treatment (5). Consequently, these enzyme activities remained significantly reduced. Similar results were observed in kidney $(28,29)$.

\section{Discussion}

Biochemical changes that occur following treatment with ochratoxin $\mathrm{A}$ involve almost all organs and tissues. It has been well documented that toxin accumulates in the various tissues. Pharmacokinetic studies have shown that ochratoxin $\mathrm{A}$ is distributed in two kinetically distinct compartments in rats, the central compartment corresponding to well perfused organs such as kidney, liver, spleen, brain, lung, heart, pancreas and testes and a peripheral compartment comprising of skin, muscle, fat and eyes $(13,30)$. The distribution pattern of ochratoxin $A$ in the rats and mice was shown to be very similar (31). A different response to ochratoxin A administration was observed when either a single or repeated doses were applied. Small doses injected repeatedly were required for the production of the severe changes in renal function, excessive weight loss and diarrhea. Deposition of toxin in the tissues was the consequence of the prolonged retention of ochratoxin $A$ in the circulation, due to its binding to the plasma proteins $(32-34)$.

Accumulation of the toxin in pancreatic tissue has been shown to be connected with lowered insulin concentrations, possibly as a result of the toxin induced inhibition of synthesis and/or release of the hormone from $\beta$-cells. The observed diabetogenic effects of ochratoxin A were attributed to the reduced level of glycolysis and glycogenesis and enhancement of gluconeogenesis and glycogenolysis (2).

In our previous studies we found that treatment with low doses of ochratoxin A over a period of 20 and 30 days affected activities of $\gamma$-glutamyl transferase, alanine aminopeptidase and alkaline phosphatase in kidney brush border membranes (17). These time points were found to be informative for the subchronical regimen of treatment. It was shown by Kane et al. that activities of renal, membrane bound enzymes such as $\gamma$-glutamyl transferase, leucine aminopeptidase, and alkaline phosphatase were significantly reduced, following subchronical ochratoxin A treatment (28).

Since it has been shown that ochratoxin A accumulated in the pancreatic tissue, we followed the activity of the same enzymes in pancreas, repeating the low dosage regimen, which results in deposition of the toxin in susceptible tissues. We included measurement of the activity of ecto- $\mathrm{Ca}^{2+} / \mathrm{Mg}^{2+}$-ATPase and ecto-5'-nucleotidase in this study since these two membrane enzymes might be involved in the metabolism of extracellular ATP and possible regulation of the ATP-dependent $\mathrm{Ca}^{2+}$ uptake in the pancreas. Calcium ions play an important role in the stimulation of enzyme secretion from exocrine pancreas. It has been proposed that a secretagogue-induced rise in cytosolic free $\mathrm{Ca}^{2+}$ triggers enzyme release from pancreatic acinar cells $(35,36)$. Activity of $\mathrm{Ca}^{2+} / \mathrm{Mg}^{2+}$-ATPase was shown to be involved in the exocytosis of the pancreatic enzymes from the membrane bound zymogen granules (37). However, the exact physiological function of ecto- $\mathrm{Ca}^{2+} / \mathrm{Mg}^{2+}$-ATPase activity is not clear. It is assumed that it may simply 
serve to regulate extracellular ATP concentration in the vicinity of the plasma membrane (38). As it has been shown for renal proximal tubule a concerted action of ecto- $\mathrm{Ca}^{2+} / \mathrm{Mg}^{2+}$-ATPase together with ecto-5'-nucleotidase is able to hydrolyze extracellular ATP to AMP yielding eventually adenosine as the product of the reaction (20).

Our results revealed reduction in the body weight gain, decrease in the protein concentration in the pancreatic homogenates and decreased activities of alanine aminopeptidase, alkaline phosphatase and ecto- $\mathrm{Ca}^{2+} / \mathrm{Mg}^{2+}$ ATPase (tab. 1 and fig. 1). The observed reductions in the enzyme activities might be reflecting the decrease in the DNA and protein synthesis that are produced by the ochratoxin A treatment $(5,39,40)$. Decrease of the enzyme activity could not be explained in terms of the mode of attachment to the cell membrane. Affected enzymes belong to groups that are bound to the membrane in different ways.

Leakage of enzymes from the damaged cell membrane is mainly influenced by the mode of attachment of the particular enzyme protein to the hydrophobic phospholipid membrane structure. The simplest form of attachment is exemplified by $\gamma$-glutamyl transferase and alanine aminopeptidase, in which the terminal sequence of hydrophobic amino acids is inserted into the membrane. There it is secured by hydrophobic interactions between the amino acids and the lipid components of the membrane. A more complex system refers to the attachment of ectoenzymes like 5'-nucleotidase, $\mathrm{Ca}^{2+} / \mathrm{Mg}^{2+}$-ATPase and alkaline phosphatase. These enzymes are anchored in the membrane through the glycan phosphatidylinositol moiety that is linked to the carboxy terminus of the polypeptide chain. Release of the enzyme may be influenced either by detergent mediated solubilisation, by enzyme cleavage (protease or phospholipase), or by the fragmentation of the membrane structure (41).

Activity of alanine aminopeptidase was already significantly affected after 20 days, but it returned to higher than normal levels in the following 15 days, in spite of the continuation of the ochratoxin A treatment. That was a surprising finding since ochratoxin A treatment produces a decrease in DNA and pròtein synthesis. Increased level of membrane bound alanine aminopeptidase might be originating from the cytosolic fraction. However, $\gamma$-glutamyl transferase, bound to the membrane in a similar way, did not exhibit significant changes at the same time. From the group of more tightly bound enzymes only ecto- $\mathrm{Ca}^{2+} / \mathrm{Mg}^{2+}$-ATPase and alkaline phosphatase were significantly reduced while ecto-5'-nucleotidase remained unchanged.

In his recent review Moss showed that alkaline phosphatase could be released either by phospholipase action or by membrane fragmentation (42). It was shown before that both $\gamma$-glutamyl transferase and 5'-nucleotidase could be solubilized at increased amounts in cholestasis, presumably by a detergent-mediated action of bile acids. There are no reports that ochratoxin A treatment is associated with increased levels of bile acids in blood or liver, much less in the pancreatic tissue. The simplest explanation for the reduced level of the membrane bound enzyme activities observed in this study is a possible alteration of membrane lipid organization and potential membrane fragmentation. Perturbation of the liver microsomal membranes has been attributed to ochratoxin $\mathrm{A}$ induced increased NADPH-dependent lipid peroxidation (29). In order to gain further insight into the effects of ochratoxin A an human and animal health in more detail, the influence of repeated low doses on the endocrine and exocrine function of the pancreatic cells must be further investigated.

\section{Conclusions}

The observed decrease in the catalytic concentration of the membrane bound enzymes measured suggests that ochratoxin $\mathrm{A}$ is connected with an impairment in the structure and function of the pancreatic plasma membrane. Acute effects reflected in the reduction of the enzyme activities could be subsequently normalized for alanine aminopeptidase in spite of the continuation of the daily ochratoxin A treatment. However, reduction in the activities of the $\mathrm{Ca}^{2+} / \mathrm{Mg}^{2+}$-ATPase and alkaline phosphatase remained unchanged. From the above observations we conclude that ochratoxin $A$ exerts its toxic effects on pancreas by diminishing catalytic concentrations of the membrane bound enzymes, most probably by inducing the release of the enzymes as a result of the impairment of the functional integrity of the cell membrane.

\section{Acknowledgements}

The present work has been supported by The Ministry of Science and Technology of Croatia, project \# 1-07-102.

\section{References}

1. Hult K, Pleština R, Habazin-Novak V, Radić B, Čeović S. Ochratoxin $A$ in human blood and Balkan endemic nephropathy. Arch Toxicol 1982; 51:313-21.

2. Subramanian S, Kanthasamy N, Balasubramanian N, Sekar N, Govindasamy S. Ochratoxin A toxicity on carbohydrate mctabolism. Bull Environ Contam Toxicol 1989; 43:180-4. 
3. Gekle M, Silbernagl S. The role of the proximal tubule in ochratoxin A nephrotoxicity in vivo: toxodyriamic and toxokinetic aspects. Renal Physiol Biochem 1994; 17:40-9.

4. Aleo MD, Wyatt RD. Schnellmann RG. Mitochondrial dysfunction is an early event in ochratoxin A but not oosporein toxicity to rat renal proximal tubules. Toxicol Appl Pharmacol 1991; 107:73-80.

5. Dirheimer G, Creppy EE. Mechanism of action of ochratoxin A. In: Castegnaro M, Pleština R, Dirheimer G, Chernozemsky IN, Bartsch H, editors. Mycotoxins, endemic nephropathy and urinary tract tumors. Lyon: IARC, June 1991:171-86.

6. Kuiper-Goodman T, Scott PM. Risk assessment of the mycotoxin ochratoxin A. Biomed Environ Sci 1989; 2:179-248.

7. Kane A, Creppy EE, Roth A, Roschenthaler R, Dirheimer G. Distribution of the $\left({ }^{3} \mathrm{H}\right)$-label from low doses of radioactive ochratoxin A ingested by rats and evidence for DNA singlestrand breaks caused in liver and kidneys. Arch Toxicol 1986; 58:219-24.

8. Marquardt RR, Frolich AA. A review of recent advances in understanding ochratoxicosis. J Anim Sci 1992; 70:3968-88.

9. Creppy EE, Chakor K, Fisher MJ, Dirheimer G. The mycotoxin ochratoxin $\mathrm{A}$ is a substrate for phenylalanine hydroxylase in isolated rat hepatocytes and in vivo. Arch Toxicol 1990; 64:279-84.

10. Omar RF, Hasinoff BB, Mejilla F, Rahimtula AD. Mechanism of ochratoxin A stimulated lipid peroxidation. Biochem Pharmacol 1990; 40:1183-91.

11. Rahimtula AD, Bereziat J-C, Bussachini-Griot V, Bartsch $H$. Lipid peroxidation as a possible cause of ochratoxin A toxicity. Biochem Pharmacol 1988; 37:4469-77.

12. Shanmugasundram KR. Terreic acid - diabetogenic mycotoxins in rats. Curr Sci 1984; 53:1290-3.

13. Fuchs $\mathrm{R}$, Appelgreen L-E, Hult K. Distribution of ${ }^{14} \mathrm{C}$ ochratoxin in the mouse monitored by whole body autoradiography. Pharmacol Toxicol 1988; 63:355-60.

14. Appelgreen L, Arova RG. Distribution of ${ }^{1+} \mathrm{C}$ ochratoxin $\mathrm{A}$ in pregnant mice. Fd Chem Toxic 1983; 21:563-8.

15. Berndt WO, Hayes AW, Phillips RD. Effects of mycotoxins on renal function: mycotoxic nephropathy. Kidney Int 1980; 18:656-64.

16. Scott PM, Walbeck W, Kennedy J. Anyeti D. Mycotoxins (ochratoxin $A$, citrinin and sterigmatocystin) and toxigenic fungi in grains and other agricultural products. Mycotoxins and Toxigenic Fungi 1972; 20:1-28.

17. Pepeljnjak S, Cepelak I, Juretić D. Effect of ochratoxin A on brush border enzymes of rat kidney. In: Castegnaro $M$, Pleština $\mathrm{R}$, Dirheimer G, Chernozemsky IN, Bartsch H, editors. Mycotoxins, endemic nephropathy and urinary tract tumors. Lyon: IARC, June 1991:273-7.

18. Balzer I, Bogdanić C, Pepeljnjak S. Rapid thin layer chromatography of aflatoxin $\mathrm{Bl}$, ochratoxin $\mathrm{A}$ and zeaalenone in corn. J Assoc Anal Chem 1978; 61:584-5.

19. Nesheim S. Isolation and purification of ochratoxins $A$ and $B$ and preparation of their methyl and ethyl esters. J Ass Anal Chem 1969; 52:975-9.

20. Čulić O, Sabolić I, Žanić-Grubišić T. The stepwise hydrolysis of adenine nucleotides by ectoenzymes of rat renal brush-border membranes. Biochim Biophys Acta 1990; 1030:143-51.

21. Fiske $\mathrm{CN}$, SubbaRow $\mathrm{Y}$. The colorimetric determination of phosphorus. J Biol Chem 1925; 66:375-88.

22. Jung K, Scholz D. An optimised assay of alanine-aminopeptidase activity in urine. Clin Chem 1980; 26:1251-4.

23. Szász G. A kinetic photometric method for serum gamma-glutamyl transpeptidase. Clin Chem 1969; 15:124-9.

24. Bradford MM. A rapid and sensitive method for the quantitation of microgram quantities of proteins, utilizing the principle of protein dye binding. Anal Biochem 1976; 72:248-54.

25. Krogh P, Gyrd-Hansen N, Hald B, Larsen S, Nielsen JP, Smith $M$. Renal enzyme activities in experimental ochratoxin $A$ in- duced porcine nephropathy: diagnostic potential of phosphoenolpyruvate carboxykinase and gamma-glutamyl transpeptidase activity. J Toxicol Envir Health 1988; 23:1-14.

26. Stockey P, Flocke K, Mathes W, Marmherz HG. 5'-Nucleotidase of chicken gizzard and human pancreatic adenocarcinoma cells are anchored to the plasma membrane via a phosphatidylinositol-glycon. Biochem J 1989; 262:33-40.

27. Mantle D. Comparison of soluble aldnine aminopeptidase in human cerebral cortex, skeletal muscle and kidney. Clin Chim Acta 1992; 207:107-18.

28. Kane A, Creppy EE, Roschenthaler R, Dirheimer G. Changes in urinary and renal tubular enzymes caused by subchronic administration of ochratoxin A in rats. Toxicology 1986; 42:233-43.

29. Siraj MY, Phillips TD, Hayes AW. Effects of the mycotoxins citrinin and ochratoxin $A$ on hepatic mixed-function oxidase and adenosinetriphosphatase in neonatal rats. J Toxicol Environ Health $1981 ; 8: 131-40$.

30. Galtier P. Pharmacokinetics of ochratoxin A in animals. In: Castegnaro M, Plestina R, Dirheimer G, Chernozemsky IN, Bartsch $\mathrm{H}$, editors. Mycotoxins, endemic nephropathy and urinary tract tumors. IARC, Lyon: June 1991:187-200.

31. Breitholtz-Emanuelsson A, Fuchs R, Hult K, Appelgreen LE. Synthesis of ${ }^{14} \mathrm{C}$-ochratoxin $\mathrm{A}$ and ${ }^{14} \mathrm{C}$-ochratoxin $\mathrm{B}$ and a comparative study of their distribution in rats using whole body radiography. Pharmacol Toxicol 1992; 70:255-61.

32. Fuchs $R$, Hult $K$. Ochratoxin $A$ in blood and its pharmacokinetic properties. Fd Chem Toxic 1992; 30:201-4.

33. Hagelberg S, Hult K, Fuchs R. Toxicokinetics of ochratoxin A in several species and its plasma-binding properties. J Appl Toxicol 1989; 9:91-6.

34. Stojković R, Hult $\mathrm{K}$, Gamulin $\mathrm{S}$, Pleština R. High affinity binding of ochratoxin $\mathrm{A}$ to plasma constituents. Biochem Int 1984; 9:33-8.

35. Ansah T-A, Molla A, Katz S. $\mathrm{Ca}^{2+}$-ATPase activity in pancreatic acinar plasma membranes. J Biol Chem 1984; 259:13442-50.

36. LeBel D, Poirier GG, Phaneuf S, St.-Jean P, Laliberte JF, Beaudoin AR. Characterization and purification of a calciumsensitive ATP diphosphohydrolase from pig pancreas. J Biol Chem 1980; 255:1227-33.

37. Dormer $\mathrm{RL}$. Regulation of intracellular $\mathrm{Ca}^{2+}$ in pancreatic acinar cells by membrane pumps and channels. In: Azzi A, Drahota Z, Papa S, editors. Molecular basis of membrane - associated diseases. Berlin: Springer-Verlag, 1989:71-83.

38. Senior $\mathrm{AE}$, Hamlyn J. Evidence that $\mathrm{Mg}^{2+}$ - or $\mathrm{Ca}^{2+}$-activated adenosine triphosphatase in rat pancreas is a plasma-membrane ecto-enzyme. Biochem J 1983; 214:59-68.

39. Krogh P. Role of ochratoxin A in disease causation. Fd Chem Toxicol 1992; 30:213-24.

40. Braunberg RC, Gantt O, Barton C, Friedman L. In vitro effects of the nephrotoxins ochratoxin $\mathrm{A}$ and citrinin upon biochemical function of porcine kidney. Arch Environ Contam Toxicol 1992; 22:464-70.

41. Alpers DH, Eliakim R, Deschryever-Keschmeti K. Secretion of hepatic and intestinal alkaline phosphatases: similarities and differences. Clin Chim Acta 1989; 186:211-24.

42. Moss DW. Release of membrane bound enzymes from cells and the generation of isoforms. Clin Chim Acta 1994; 226:131-42.

Tihana Žanić-Grubišić

Department of Medical Biochemistry

Faculty of Pharmacy and Biochemistry

University of Zagreb

A. Kovačića 1

P. O. Box 156

10000 Zagreb

Croatia 